ISSN $0258-7122$

Bangladesh J. Agril. Res. 32(3) : 393-402, September 2007

\title{
RESPONSE OF OKRA SEED CROP TO SOWING TIME AND PLANT SPACING IN SOUTH EASTERN HILLY REGION OF BANGLADESH
}

\author{
M. MoniruZZaman ${ }^{1}$, M. Z. UdDin ${ }^{2}$ AND A. K. ChOUdhURY ${ }^{3}$
}

\begin{abstract}
A field experiment on okra cv. BARI Dherosh-1 comprising four sowing times starting from February to May (15th day of each month) at monthly interval and four spacings $(60 \times 30,60 \times 40,60 \times 50$, and $60 \times 60 \mathrm{~cm})$ was conducted at the Agricultural Research Station (ARS), Raikhali, Rangamati Hill District to find out the most suitable sowing time and optimum plant spacing for the two consecutive years of 1997 and 1998. The highest seed yield (2.97 t/ha) was recorded from 15 April sowing closely followed by 15 March sowing (2.77 $\mathrm{t} / \mathrm{ha}$ ) whereas the best quality seed was obtained from 16 February $(88.7 \%$ germination and 29.75 seed vigour index) and 15 March $(83.7 \%$ germination and 28.80 seed vigour index) sowing. Plant spacing of $60 \times 40 \mathrm{~cm}$ produced the highest seed yield of okra (2.86 t/ha) followed by $60 \times 30 \mathrm{~cm}$ spacing $(2.80$ $\mathrm{t} / \mathrm{ha}$ ). The germination percentage and seed vigour index were unaffected due to different plant spacings. 15 April sowing accompanied with $60 \times 30 \mathrm{~cm}$ spacing gave the highest seed yield ( $3.13 \mathrm{t} / \mathrm{ha}$ ) closely followed by $60 \times 30 \mathrm{~cm}$ spacing with the same sowing time $(3.06 \mathrm{t} / \mathrm{ha})$. The seed yield did not decline in 15 March sowing having similar spacings.
\end{abstract}

Key Words: Okra (Abelmoschus esculentus (L.) Moench), sowing time, plant spacing, hilly regions.

\section{Introduction}

Okra (Abelmoschus esculentus (L.) Moench) originated in Asia and Africa (Thomson and Kelly, 1979) is an important summer vegetable in Bangladesh (Rashid, 1999). It is a nutritious vegetable which plays an important role to meet the demand of vegetables of the country when vegetables are scanty in the market (Ahmed, 1995). These green fruits are rich sources of vitamins, calcium, potassium, and other minerals. In Bangladesh, it is known as Dherosh, which is also called Bhindi in India and Pakistan (Rashid, 1999). Its tender pods are used as vegetables. It is cultivated throughout Bangladesh but its average national yield is poor, only 3.07 t/ha (Anon., 2000). The yield is very low as compared to the yield 97-10 t/ha of other developed countries of the world (Thomson and

${ }^{1}$ Scientific Officer (Horticulture) ARS, Raikhali Chandraghona, Rangamati Hill District4531, ${ }^{2}$ Senior Scientific Officer (OFRD), Comilla, ${ }^{3}$ Senior Scientific Officer OFRD, Sylhet, Bangladesh. 
Kelly, 1979). The yield could reach as high as 30 t/ha (Koay and Chua, 1978). The unavailability of quality seed is the most important reason for low yield. Sowing time has a great impact on seed production and quality of okra (Singh et al., 1986; Hossain et al., 1999; Yadav and Dhankhar, 2001). Plant population or plant density is another important factor that affects okra seed production. Suitable plant spacing can lead to optimum seed yield whereas too high or too low plant spacing could result in relatively low yield and quality (Absar and Siddique, 1982). So, optimum plant spacing can lead to optimum seed yield. The plant spacing for okra seed production suggested by different authors ranges from 20 to $40 \mathrm{~cm}$ and 30 to $60 \mathrm{~cm}$ between rows (Hossain et al., 1999; Rastagie el al., 1987; Thakur and Arora, 1986; Khan and Jaisal, 1988). The information available so far regarding sowing time and plant spacing for okra seed production is inadequate under north-eastern hilly areas of Bangladesh. Therefore, the present investigation was carried out to find out the most suitable sowing time and optimum plant spacing to achieve higher yield and quality seed of okra (cv. BARI Dherosh-1).

\section{Materials and Method}

The experiment was conducted at the Agricultural Research Station, Raikhali in the district of Rangamati during the summer seasons of 1997 and 1998. The climate of the area is subtropical with extreme hot during summer. The temperatures from February to August during 1997 and 1998 were more or less similar but total rainfall of 1998 was higher than that of 1997 (Fig. 1). The experimental field belongs to AEZ 29 with the piedmont plain soil having medium loamy to moderately fine texture (sandy clay loam). The soil was poor in organic matter and moderately acidic. Nitrogen, phosphorus, and potassium were low in soil. $\mathrm{N}$ and $\mathrm{P}$ were below critical limit and $\mathrm{K}$ was just above the critical level (Table 1). The experiment was laid out in a split-plot design with three replications, having four sowing times (15 February, 15 March, 15 April and 15 June) as main plot treatment and four spacings $(60 \times 30,60 \times 40,60 \times 50$, and 60 $\times 60 \mathrm{~cm})$ as sub-plot treatments. There were 16 treatment combinations altogether. The unit plot size was $6 \mathrm{~m} \times 2.4 \mathrm{~m}$. 
Table 1. Soil Characteristics of the experimental site (Islam, 1991).

\begin{tabular}{lc|c}
\hline Parameter & Soil test value & Critical level \\
\hline Texture & Sandy clay loam & - \\
$\mathrm{pH}$ & 5.7 & - \\
Organic matter $(\%)$ & 0.63 & - \\
Total nitrogen $(\%)$ & 0.079 & 0.12 \\
Available phosphorous $(\mu \mathrm{g} / \mathrm{g}$ soil) & 9.0 & 10 \\
Available potassium $(\mathrm{meq} / 100 \mathrm{~g}$ soil) & 0.17 & 0.12 \\
\hline
\end{tabular}

Manures and fertilizers were applied to the soil @ 150-100-150 kg/ha N, $\mathrm{P}_{2} \mathrm{O}_{5}, \mathrm{~K}_{2} \mathrm{O}$, and $10 \mathrm{t} / \mathrm{ha}$ well rotten cowdung. The total amount of cowdung, TSP, and MP and one-fourth quantity of urea and MP were applied as basal and the rest was top dressed into three equal installments 30, 45, and 60 days after planting. Seeds of BARI Dherosh-1 were soaked in tap water for 24 hours and they were dibbled with 2 seeds/hill on monthly interval starting from 15 February of 1977 and 1998. All the recommended cultural and plant protection measures were followed throughout the experimental period.

Days to 1st and 50\% flowering, yield and yield attributes were recorded from randomly selected 10 plants from the inner rows of the plots. Fresh okra seed of each treatment was placed in treated sands in laboratory to find out germination $\%$ and seed vigour index. Seed vigour index was calculated by using the formula suggested by Agarwal (1999) which is as follows :

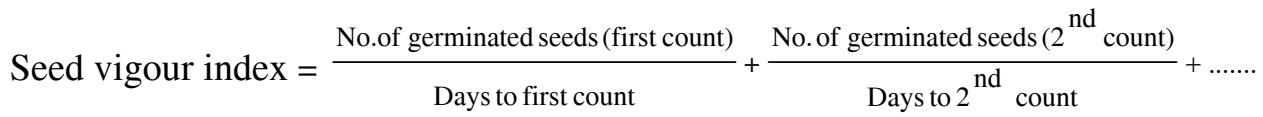

$\underline{\text { No. of germinated seeds (final count) }}$

Days to final count

The treatment means were separated by Least Significant Test (LSD) at 5\% level of significance for interpretation of the results.

\section{Results and Discussion}

\section{Effects of sowing time}

Days to 1 st and $50 \%$ flowering and yield attributes of okra were significantly influenced by time of sowing (Table 1 and 2). Days required for 1st flowering ranged from 34 to 49.5. The earliest flowering observed in 15 May sowing (34 days) followed by 15 April sowing (34.5 days). Days to first harvest were minimum in 15 April sowing (68.5 days) closely followed by 15 May sowing (69.5 days). 15 February sowing took maximum days ( 79 days). The tallest plant at final harvest $(1.89 \mathrm{~m})$ was recorded from 15 April sowing followed 


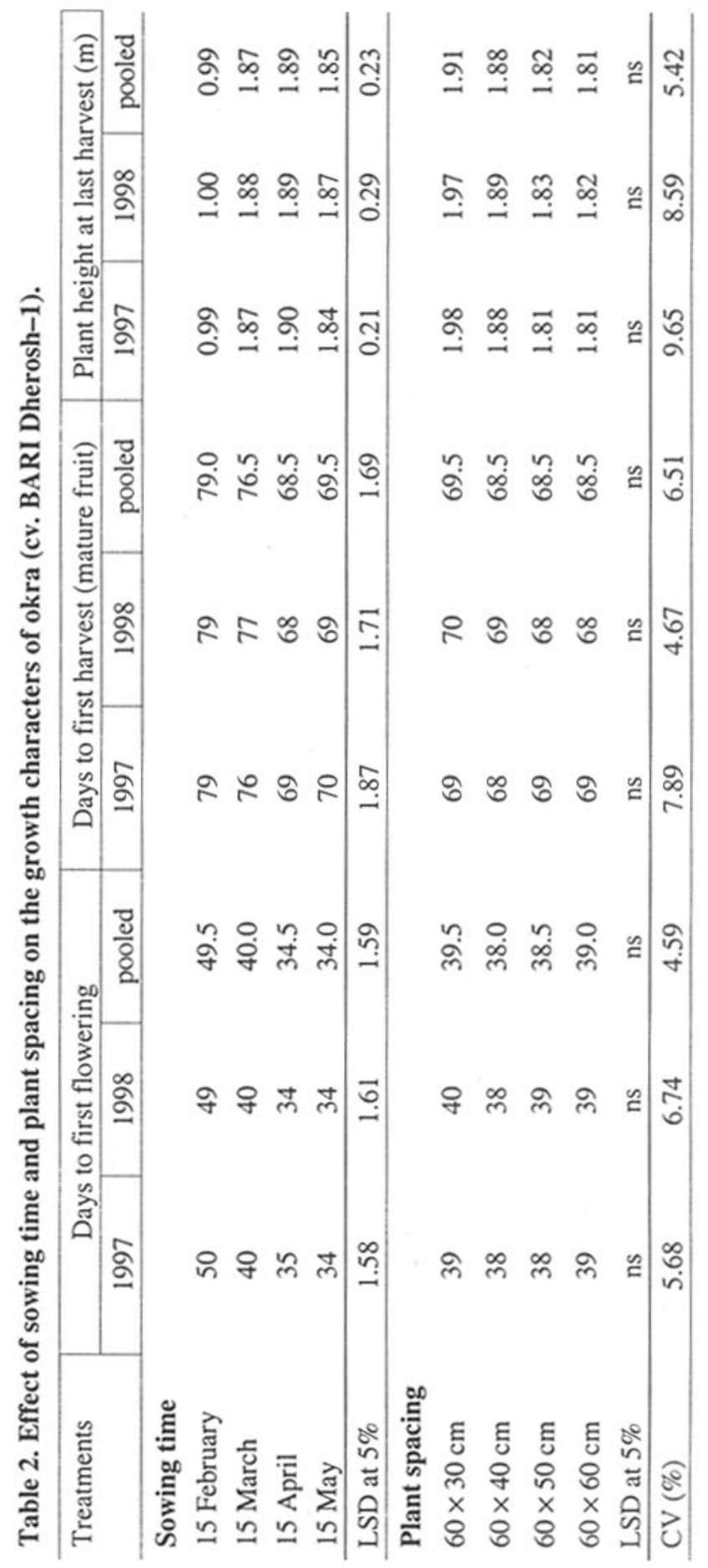


by 15 March $(1.87 \mathrm{~m})$ and 15 May $(1.85 \mathrm{~m})$ sowings. The shortest plant $(0.99 \mathrm{~m})$ was recorded from 15 February sowing which was statistically different from other sowings. It might be due to prevailing low temperature in February (average $\max .25 .5^{\circ} \mathrm{C}$ and $\min .14 .75^{\circ} \mathrm{C}$ ), which ultimately restricted vegetative growth of the plants (Fig. 1). The observation is in agreement with that of Hossain et al. (1999).

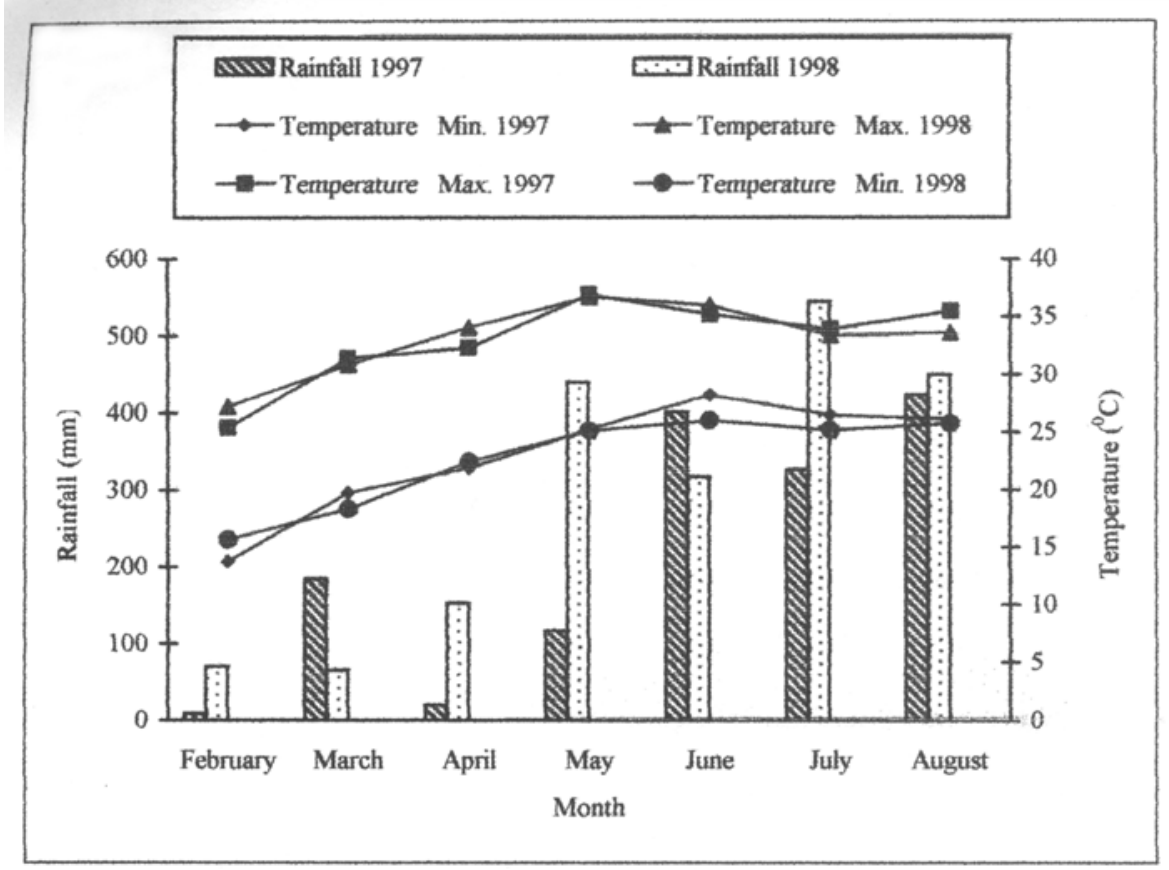

Fig. 1. Air temperature and rainfall recorded during experimentation in 1997 and 1998 at Raikhali.

The significantly highest matured fruits per plant (26.86), longest matured fruits $(19.53 \mathrm{~cm})$, maximum fruit diameter $(2.03 \mathrm{~cm})$, seeds per fruit $(65.01)$, 1000 -seed weight $(64.01 \mathrm{~g})$, seed yield per plant (77.98 g), and yield (2.97 t/ha) were recorded from 15 April sowing. They were identical to 15 March sowing. Significantly the lowest values for those parameters were observed in 15 February sowing. The result is in close conformity with that of Hossain et al. (1999).

Seeds sown in either 15 February or 15 March produced the best quality seed ( $88.7 \%$ and $83.7 \%$ germination, 29.75 and 28.80 vigour index, respectively), whereas 15 April and 15 May sowings produced inferior seed (70\% and 72.9\% germination 18.75 and 23.75 vigour index, respectively). The highest germination percentage and seed vigour index was obtained from 15 February and 15 March 
sowing because the fruits faced lower amount of rainfall during their harvesting period compared to others (Fig. 1). The present findings are in close conformity of Huda and Samirudding (1987) who recommended that mid February to mid March are the best time for quality seed production of okra under Bangladesh condition.

\section{Effects of plant spacings}

All the characters studied were significantly affected due to different plant spacings treatment except days to first flowering, days to first harvest, percentage of germination, and seed vigur (Table 1, 2, and 3). The closest spacing $(60 \times 30$ $\mathrm{cm}$ ) forced to grow taller plant and increase seed yield per hectare but reduced number of mature fruits per plant, length and diameter of mature fruit, number of seeds per fruit, 1000-seed weight, and seed yield per plant. Rastogi et al. (1987) also found similar results. Maximum number of mature fruits per plnat (26.70) was recorded from the widest spacing $(60 \times 60 \mathrm{~cm})$ having maximum length $(17.67 \mathrm{~cm})$ and diameter $(1.98 \mathrm{~cm})$ of fruit. The lowest number of matured fruits was obtained from the closest spacing $(60 \times 20 \mathrm{~cm})$ that produced fruits of the lowest length $(15.90 \mathrm{~cm})$ and diameter $(1.80 \mathrm{~cm})$. This might be due to competition for nutrient and space among the plants owing to maximum plant population. This result is in close conformity of Zanin and Kimoto (1988). However, there was no significent difference between $60 \times 50 \mathrm{~cm}$ and $60 \times 60 \mathrm{~cm}$ spacing with respect to number of mature fruits per plant, length and diameter of mature fruits. No significant difference was also observed between 60 x $40 \mathrm{~cm}$ and $60 \times 50 \mathrm{~cm}$ spacing in terms of those three parameters. The highest number of seeds per fruit (62.2) and 100-dry seed weight (64.71 g) was recorded in the widest spacing $(60 \times 60 \mathrm{~cm})$ identically followed by $60 \times 50 \mathrm{~cm}$ spacing $(59.9$ and $63.95 \mathrm{~g}$, respectively). There was no significant difference observed between $60 \times 40 \mathrm{~cm}$ and $60 \times 50 \mathrm{~cm}$ spacing in respect of number of seeds per fruit and weight of 100 dry seeds. Similar trend was also observed in respect of seed yield per plant. The highest seed yield per plant was obtained from the widest spacing $(60 \times 60 \mathrm{~cm})$ closely followed by $60 \times 60 \mathrm{~cm}$ spacing $(83.10 \mathrm{~g})$. The result is in agreement with the report of Singh et al. (1986) who 


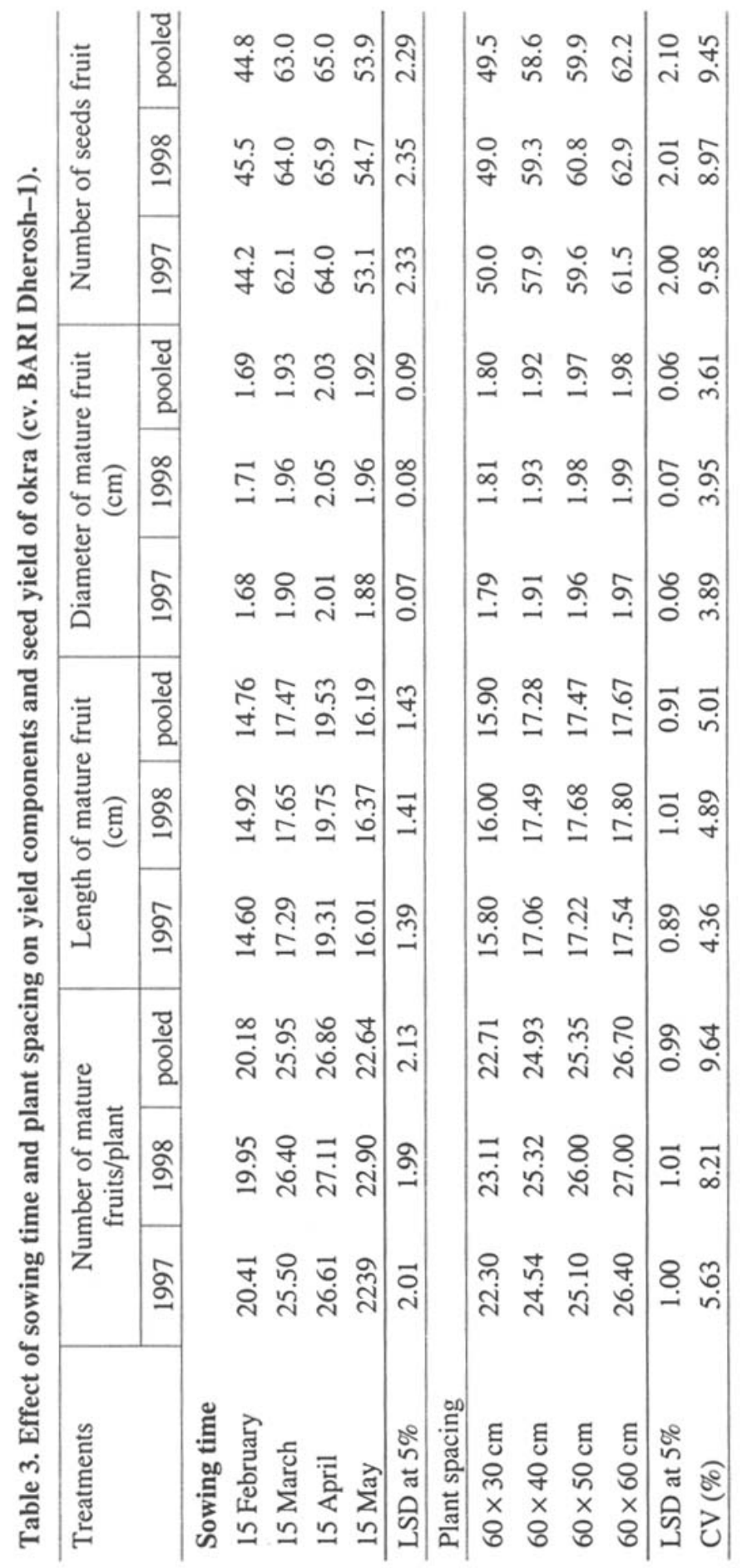




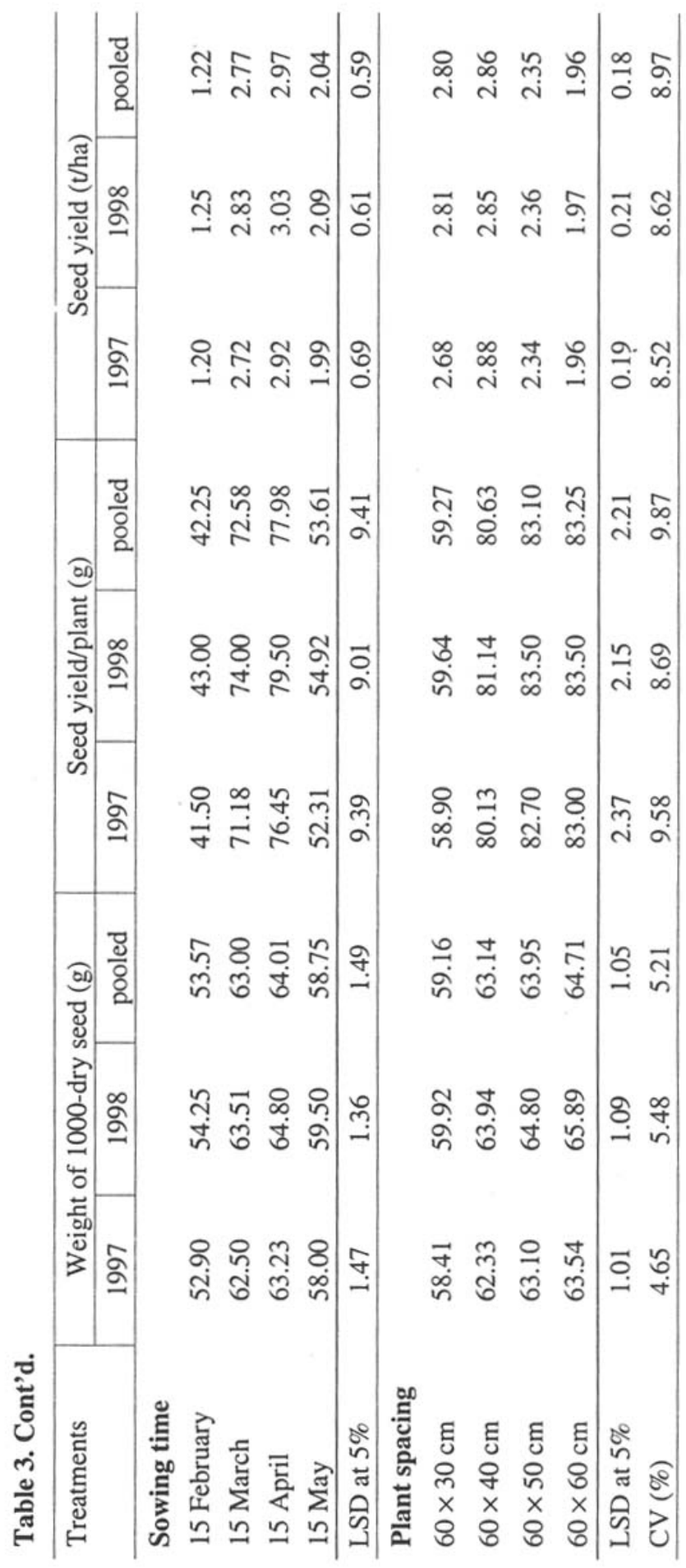


Table 4. Effect of sowing time and plant spacing on qualitative characters of okra seed.

\begin{tabular}{l|c|c|c|c|c|c}
\hline \multirow{2}{*}{ Treatments } & \multicolumn{3}{|c|}{ Germination (\%) } & \multicolumn{3}{c}{ Seed vigour index } \\
\cline { 2 - 7 } & 1997 & 1998 & pooled & 1997 & 1998 & pooled \\
\hline Sowing time & \multicolumn{7}{c}{} & & & & \\
15 February & 88.3 & 89.1 & 88.7 & 29.5 & 30.0 & 29.75 \\
15 March & 84.2 & 83.2 & 83.7 & 28.9 & 28.7 & 28.80 \\
15 April & 70.4 & 69.5 & 70.0 & 18.4 & 19.1 & 18.75 \\
15 May & 72.3 & 73.4 & 72.9 & 23.1 & 24.3 & 23.7 \\
\hline LSD at 5\% & 1.2 & 0.98 & 1.1 & 0.88 & 1.06 & 1.05 \\
\hline Plant spacing & 79.4 & 78.8 & 79.1 & 28.4 & 28.33 & 28.37 \\
$60 \times 30 \mathrm{~cm}$ & 81.3 & 81.5 & 81.4 & 28.62 & 28.68 & 28.65 \\
$60 \times 40 \mathrm{~cm}$ & 81.5 & 80.9 & 81.2 & 28.73 & 28.77 & 28.75 \\
$60 \times 50 \mathrm{~cm}$ & 81.9 & 81.8 & 81.9 & 28.78 & 28.80 & 28.75 \\
$60 \times 60 \mathrm{~cm}$ & $\mathrm{~ns}$ & $\mathrm{~ns}$ & $\mathrm{~ns}$ & $\mathrm{~ns}$ & $\mathrm{~ns}$ & $\mathrm{~ns}$ \\
\hline LSD at 5\% & 8.98 & 8.87 & 8.95 & 6.54 & 6.32 & 6.45 \\
CV $(\%)$ &
\end{tabular}

Interaction effect between percentage of germination and seed vigour index was not significant.

reported seed yield of okra was highest at closer spacing. The lowest yield of seeds per plant $(59.27 \mathrm{~g})$ was obtained from the closest spacing $(60 \times 30 \mathrm{~cm})$. The highest seed yield per hectare $(2.86 \mathrm{t})$ was recorded from $60 \mathrm{x} 40 \mathrm{~cm}$ spacing closely followed by $60 \times 30 \mathrm{~cm}$ spacing $(2.80 \mathrm{t} / \mathrm{ha})$. The widest spacing $(60 \times 60$ $\mathrm{cm})$ gave the lowest seed yield per hectare $(1.96 \mathrm{t})$. The highest seed yield in the closest spacing might be resulted from increased plant population. The maximum seed yield of okra achieved by sowing seeds at closer spacing is also reported by Sarnaik et al. (1986), Khan and Jaisal (1988), Pandey et al. (1979). No significant difference was observed in respect of germination percentage and seed vigour index due to different spacings (Table 3 ).

\section{Combined effects of sowing time and plant spacing}

The highest seed yield per plant was obtained from the combination of 15 April sowing and $60 \times 60 \mathrm{~cm}$ spacing $(90.81 \mathrm{~g})$ closely followed by the same sowing time at $60 \times 50 \mathrm{~cm}$ spacing $(89.25 \mathrm{~g}) .15$ March sowing at $60 \times 60 \mathrm{~cm}$ spacing or the same sowing time at $60 \times 50 \mathrm{~cm}$ spacing also produced the highest seed yield per plant followed by 15 April sowing at $60 \times 60 \mathrm{~cm}$ spacing. 15 April sowing coupled with $60 \times 30 \mathrm{~cm}$ spacing produced maximum seed yield per hectare $(3.13$ t) and closely followed by $60 \times 40 \mathrm{~cm}$ spacing at the same sowing time $(3.06 \mathrm{t})$ as well as 15 March sowing either at $60 \times 30 \mathrm{~cm}(3.00 \mathrm{t})$ or $60 \times 40 \mathrm{~cm}$ spacing $(2.98 \mathrm{t})$. There was no significant difference in seed yield per hectare among the above four treatment combinations. Palanisamy et al. (1986) reported that seed sowing at $60 \times 30 \mathrm{~cm}$ spacing in March, April or May gave the best quality seed in South Indian condition.

It is revealed that okra seeds may be sown on 15 March at $60 \times 30$ or $60 \times 40$ $\mathrm{cm}$ for higher seed yield and quality seed in the hilly region. 


\section{References}

Absar, N. and M. A. Siddique. 1982. Influence of plant density on the yield of three varieties of okra. Bangladesh J. Agric. 7 (3-4): 15-21.

Agrawal, B. L. 1999. Seed Technology ( $3^{\text {rd }}$ ed.). Oxford and IBH Publishing Co. pvt. Ltd. New Delhi, India. 829 P.

Ahmed, K. U. 1995. Pal-Phul O Shak-Shabji (In Bengali) 5th ed. Mrs Mumtaj Kamal. Mirpur, Dhaka, Bangladesh. 400p.

Anonymous. 2000. Yearbook of Agricultural Statistics of Bangladesh, Bangladesh Bureau of Statistics (BBS). Ministry of planning, Govt. of the People's Republic of Bangladesh. p. 96.

Hossain, M. D., M. A. Salam, M. S. Islam and M. A. T. Masud. 1999. Yield and quality of Okra (BARI Dherosh-1) seed as influenced by time of sowing and plant spacing. Bangladesh J. Seed Sci. Tech. 3 (1-2): 83-87.

Huda, M. N. and M. Samiruddin. 1987. Vegetable Seed Technology in Bangladesh. $1^{\text {st }}$ Pub. BADC, Dhaka. 282 p.

Khan, A. R. and R. C. Jaisal. 1998. Effect of nitrogen, plant spacing and green fruit pickings on the seed production of okra (Abelmoschus esculentus (L.) Moench). Veg. Sci. 15 (1): 8-14.

Koay, S. H. and S. E. Chua. 1978. Effect of fertilizers on vegetative growth and pod production in okra (Hibiscus esculentus L.). Singapore J. Prio. Ind. 6: 76-79.

Palanisamy, V., K. Vanangamudi, T. Jayaraj and T. V. Karivaratharaju. 1986. Influence of date of sowing in bhindi (Abelmschus esculentus (L.) Moench.). South Indian Hort. 34 (1): 23-25.

Pandey, U. C. and I. J. Singh. 1979. Effect of nitrogen, plant population and seed moisture regimes on sed production of okra (Abelmoschus esculentus (L.) Moench). Vegetable Sci. 6 (2): 81-91.

Rashid, M. M. 1999. Shabjibiggayan (In Bengali). Rashid Publishing House, 94 Old DOHS, Dhaka-1206. p. 49.

Rastogi, K. B., P. P. Sharma, N. P. Sing, B. N. Korla. 1987. Effect of different levels of nitrogen and plant spacing on seed yield of okra (Abelmoschus esculentus (L.) Moench). Vegetable Sci. 14 (2): 120-123.

Sarnaik, D. A., B. S. Baghel and K. 1986. Response of okra (Abelmoschus esculentus (L.) Moench) seed crop to varying interrow and intrarow spacings. J. Farming Systems. 2(3-4): 13-15.

Sing, K. P., Y. S. Malik, S. Lal and M. L. Pandita. 1986. Effects of planting dates and spacing on seed production of okra (Abelmoschus esculentus (L). Moench). Haryana J. Hortic. Sci. 15(3-4): 267-271.

Thakur, M. R. and S. K. Arora. 1986. Cited in vegetable Crops in India (eds. T. K. Bose and M. G. Som). Naya Prakash, 200, Bidhan Sarani, Calcata. pp. 613-622.

Thomson, H. C. and W. C. Kelly. 1979. (3rd ed.) Vegetables crops. Mcgrow Hill Co. New York. p. 562.

Yadav, S. K. and B. S. Dhankar. 2001. Seed production and quality of okra (Abelmoschus esculentus (L.) Moench) as affected by sowing time and position of fruit on plant. Seed Res. 29(1): 47-51.

Isam, A. T. S. Z. (ed.). 1991. Inventory of Soil Fertility Status of Agricultural Research (Hill Farming) Sub station, Raikhali. p. 13.

Zanin, A. C. W. and T. Kimoto. 1980. Effect of plant spacing and fertilizers on okra seed production. Revista Brasileira de sementes 2(3): 105-192. 